\title{
Association between Liver Fibrosis and Incident Dementia in the UK Biobank Study
}

Neal S. Parikh, MD, MS ${ }^{1 ;}$ Hooman Kamel, MD, MS¹; Cenai Zhang, $\mathrm{MS}^{1}$; Sonal Kumar, MD, MPH²; Russell Rosenblatt, MD, MS²; Pascal Spincemaille, PhD³; Ajay Gupta, MD, MS³; David E. Cohen, MD, PhD'; Mony J. de Leon, EdD³; Rebecca F. Gottesman, MD, $\mathrm{PhD}^{5}$; Costantino ladecola, $\mathrm{MD}^{1}$

${ }^{1}$ Clinical and Translational Neuroscience Unit, Feil Family Brain and Mind Research Institute and Department of Neurology, Weill Cornell Medicine, New York, NY, USA. ${ }^{2}$ Division of Gastroenterology and Hepatology, Department of Medicine, Weill Cornell Medicine, New York, NY, USA.

${ }^{3}$ Department of Radiology, Weill Cornell Medicine, New York, NY, USA.

${ }^{4}$ Division of Gastroenterology, Hepatology and Endoscopy, Brigham and Women's Hospital, Harvard Medical School, Boston, MA, USA.

${ }^{5}$ Stroke Branch, National Institute of Neurological Disorders and Stroke Intramural Research Program, Bethesda, MD, USA.

Correspondence: Neal S Parikh, MD, MS; 420 E 70 th St, $4^{\text {th }}$ Floor; New York, NY 10021. Telephone: 646-962-3829. Fax: 888-869-3929. Email: nsp2001@med.cornell.edu. 


\section{Abstract}

Background: There is growing recognition of the role of chronic liver disease in brain health, but the impact of liver fibrosis on dementia risk was unclear. We evaluated the association between liver fibrosis and incident dementia using data from a large prospective cohort study.

Methods: We performed a cohort analysis using data from the UK Biobank study, which prospectively enrolled approximately 500,000 adults starting 2007 and continues to follow them. Liver fibrosis was defined using validated cutoffs of the Fibrosis-4 (FIB-4) liver fibrosis score. The primary outcome was incident dementia, ascertained using a validated approach based on participants' hospital record and mortality data. Secondary outcomes were Alzheimer's disease and vascular dementia. We excluded participants with prevalent dementia. We used Cox proportional hazards models to evaluate the association between liver fibrosis and incident dementia while adjusting for potential confounders. In additional models, the FIB-4 score was used as a continuous independent variable. Prespecified interaction analyses tested for effect modification by sex, metabolic syndrome, and apolipoprotein E4 carrier status.

Results: Among 455,226 participants included in this analysis, the mean age was 56.5 years and $54 \%$ were women. Standard liver chemistries were largely in the normal range. However, $2.17 \%(95 \% \mathrm{Cl}, 2.13-2.22 \%)$ had liver fibrosis based on their FIB-4 score. The rate of dementia per 1,000 person-years was $1.76(95 \% \mathrm{Cl}, 1.50-2.07)$ in participants with liver fibrosis and $0.52(95 \% \mathrm{Cl}, 0.50-0.54)$ in those without. After adjusting for demographics, socioeconomic deprivation, educational attainment, metabolic syndrome, hypertension, diabetes, dyslipidemia, and tobacco and alcohol 
medRxiv preprint doi: https://doi.org/10.1101/2022.02.09.22270729; this version posted February 10, 2022. The copyright holder for this preprint (which was not certified by peer review) is the author/funder, who has granted medRxiv a license to display the preprint in perpetuity. All rights reserved. No reuse allowed without permission.

Parikh et al. 3

use, liver fibrosis was associated with an increased risk of dementia $(\mathrm{HR}, 1.52 ; 95 \% \mathrm{Cl}$, 1.22-1.90). An independent association was also noted between FIB-4, treated as a continuous variable, and dementia (HR per unit, 1.29; $95 \% \mathrm{Cl}, 1.20-1.39)$. Effect modification by sex, metabolic syndrome, and apolipoprotein E4 carrier status was not seen.

Conclusion: Liver fibrosis in middle age was associated with an increased risk of incident dementia, independent of metabolic syndrome and shared risk factors. Liver fibrosis may be an underrecognized risk factor for dementia. 
Parikh et al. 4

\section{Introduction}

Common pathologies associated with cognitive impairment, such as those characteristic of Alzheimer's disease and related dementias, incompletely explain the variance in agerelated cognitive decline. ${ }^{1}$ There is growing appreciation of the multiplicity of pathogenic factors underlying cognitive impairment, ${ }^{2}$ and recognition that medical comorbidities may contribute to cognitive impairment and dementia. ${ }^{3}$

The liver-brain axis is a burgeoning area of investigation, underpinned by mechanistic and epidemiological studies that substantially expand the scope of liver-brain pathways beyond ammonia clearance. ${ }^{4-6}$ Chronic liver disease occurs along a spectrum, with liver fibrosis occurring in response to chronic liver injury from a variety of causes. ${ }^{7}$ Apart from people with clinically apparent cirrhosis, which is the end stage of liver fibrosis, individuals with liver fibrosis commonly have normal liver enzymes and lack clinical signs and symptoms typically associated with liver disease. ${ }^{8-12}$ Even in this subclinical stage, liver fibrosis is associated with cardiovascular disease. ${ }^{13-17}$

There are few data on the relationship between liver fibrosis and brain health at the population level. We previously demonstrated the cross-sectional association between liver fibrosis and worse cognitive performance in a population-based sample. ${ }^{18}$ However, longitudinal data regarding incident dementia are lacking. Therefore, using data from a large, prospective cohort, we evaluated the hypothesis that liver fibrosis is associated with an increased risk of future dementia. 
Parikh et al. 5

\section{Methods}

\section{Design}

This is a retrospective cohort study using data from the United Kingdom (UK) Biobank. The UK Biobank is a prospective cohort study that recruited approximately 500,000 participants between 40-69 years of age from across the UK. ${ }^{19}$ In the UK, nearly all people are registered with a general practitioner through the National Health Service; eligible participants were identified from National Health Service registers based on age and residence within reasonable traveling distance of one of 35 assessment centers around the UK. Participants were sent invitation letters by post. Baseline assessments occurred from 2007 to 2010, and included detailed health questionnaires, physical measurements, and collection of biological samples for laboratory panels and genotyping. Standard laboratory panels included blood count and blood biochemistry tests, such as those required for this analysis. Participants provided signed, informed consent to be followed longitudinally, including through linked hospital record and death data. Based on these linked data, the UK Biobank includes time-to-event data for common health outcomes, including dementia, in addition to death and loss to followup. UK Biobank data, including externally collected data such as hospital record and death registry data, are subjected to extensive data stewardship measures designed to ensure data integrity. ${ }^{20}$ The data that support the findings of this study are made available in an anonymized format to qualified investigators upon application to the UK Biobank. Analytic methods will be made available upon reasonable request. The Weill Cornell Medicine institutional review board certified these analyses of deidentified data as exempt from review. 
medRxiv preprint doi: https://doi.org/10.1101/2022.02.09.22270729; this version posted February 10, 2022. The copyright holder for this preprint (which was not certified by peer review) is the author/funder, who has granted medRxiv a license to display the preprint in perpetuity.

Parikh et al. 6

\section{Population}

From among the approximately 500,000 people in the UK Biobank, we included all participants who attended a baseline assessment center visit while excluding participants with prevalent dementia, missing exposure variable data, possible acute hepatitis, and severe thrombocytopenia. Participants who had prevalent dementia were identified based on a dementia diagnosis concurring with or preceding baseline assessment. We excluded people with possible acute hepatitis (aspartate aminotransferase or alanine aminotransferase $\geq 250$ international units/liter), ${ }^{21}$ and people with severe thrombocytopenia $(<50,000 \text { per microliter })^{22}$ to minimize the influence of these conditions on our findings through impact on the liver fibrosis score. These exclusions resulted in a study sample of 455,226 participants (eFigure1 in the Supplement).

\section{Measurements}

The exposure variable was liver fibrosis. We calculated the Fibrosis-4 (FIB-4) score for each participant according to its formula:

(age $\times$ aspartate aminotransferase $) \div($ platelets $\times \sqrt{\text { alanine aminotransferase }})$,

with age in years, aminotransferases in units/liter, and platelet count in $10^{9} /$ liter. $^{23}$ In the primary analysis, we classified participants with FIB-4 score $>2.67$ as having liver fibrosis and those with FIB-4 $\leq 2.67$ as not having liver fibrosis. ${ }^{23,24} \mathrm{~A}$ secondary approach treated the FIB-4 score as a continuous variable, including visualization as a restricted cubic spline. The FIB-4 score has been validated to have good accuracy for liver fibrosis across multiple conditions, including nonalcoholic fatty liver disease, alcoholic liver disease, hepatitis $B$, and hepatitis $C .{ }^{24-30}$ As evidence of its validity in 
people unselected for individual liver conditions, a high FIB-4 score among the general population was associated with a 17-fold higher risk of future clinically apparent liver disease. ${ }^{31}$ Our approach of evaluating liver fibrosis in the general population, irrespective of underlying etiology, is consistent with other efforts to understand the role of liver fibrosis broadly in human disease.$^{13,14,32,33}$ Furthermore, this approach is consistent with emerging liver fibrosis screening paradigms $\mathrm{s}^{8,34}$ and accounts for the real-world overlap between chronic liver conditions such as alcoholic and presumed non-alcoholic fatty liver disease..$^{35}$

The primary outcome was incident all-cause dementia. UK Biobank developed algorithms to identify dementia based on medical history, hospital records, and mortality register data using International Classification of Diseases versions 9 and 10 diagnosis codes ${ }^{36}$ The UK Biobank dataset contains time-to-event data for dementia derived using these algorithms for the entire study cohort. In a validation study of UK Biobank data, the positive predictive value of this approach was $85 \%$ for all-cause dementia, $71 \%$ for Alzheimer's disease, and 33\% for vascular dementia. ${ }^{37}$ Alzheimer's disease and vascular dementia were included as secondary outcomes in the present analysis.

We tabulated a variety of population characteristics. Demographics included age, sex, self-reported race/ethnicity, socioeconomic status, and educational attainment. Race/ethnicity were categorized as Asian, Black, other/multiple, and White, with categorization reflecting UK demographics. Socioeconomic status at baseline was measured using the Townsend deprivation index ${ }^{38}$ which incorporates employment 
status, automobile ownership, home ownership, and household crowding; higher scores indicate worse socioeconomic deprivation. Educational attainment was categorized as professional/university degree, pre-university/secondary education qualifications, vocational training, and certificate of secondary education. Cardiometabolic risk factors were assessed at baseline. Hypertension was defined as self-reported diagnosis of hypertension, systolic blood pressure $\geq 130 \mathrm{mmHg}$, diastolic blood pressure $\geq 80$ $\mathrm{mmHg}$, or use of anti-hypertensive medications. Diabetes was defined as a selfreported diagnosis of diabetes, hemoglobin $\mathrm{A} 1 \mathrm{C} \geq 6.5 \%$, or use of diabetes medications. Metabolic syndrome was defined as having at least 3 of the following 5 features: waist circumference $\geq 102$ centimeters in men or $\geq 88$ centimeters in women, triglycerides $\geq$ 150 milligrams per deciliter, HDL cholesterol $<40$ milligrams per deciliter in men or $<50$ milligrams per deciliter for women, systolic blood pressure $\geq 130 \mathrm{mmHg}$ or diastolic blood pressure $\geq 85 \mathrm{mmHg}$, and serum glucose $\geq 100$ milligrams per deciliter. Dyslipidemia was defined as use of lipid-lowering medications or total cholesterol $\geq 200$ milligrams per deciliter. BMI was categorized using standard cutoffs for normal (18.5$\left.24.99 \mathrm{~kg} / \mathrm{m}^{2}\right)$, underweight $\left(<18.5 \mathrm{~kg} / \mathrm{m}^{2}\right)$, overweight $\left(25-29.99 \mathrm{~kg} / \mathrm{m}^{2}\right)$, and obesity $\left(\geq 30 \mathrm{~kg} / \mathrm{m}^{2}\right)$. Tobacco use was categorized as never smoker versus smoker. Alcohol use was categorized based on consumption frequency as non-drinker, less than once weekly, 1-4 times per week, and daily or almost daily. Patients reporting any prevalent chronic liver condition, including cirrhosis, alcoholic liver disease, hepatitis and noninfectious liver disease during their nurse-led interview were categorized as having a clinically known liver condition. Participants with at least one apolipoprotein E4 allele were categorized as carriers. The apolipoprotein gene was directly genotyped for UK 
medRxiv preprint doi: https://doi.org/10.1101/2022.02.09.22270729; this version posted February 10, 2022. The copyright holder for this preprint (which was not certified by peer review) is the author/funder, who has granted medRxiv a license to display the preprint in perpetuity.

All rights reserved. No reuse allowed without permission.

Parikh et al. 9

Biobank participants, and we used standard definitions to assign genotypes based on rs429358 and $r s 7412$ alleles. ${ }^{39,40}$

\section{Statistical Analyses}

Survival analysis was used to estimate cumulative risks while censoring at the time of death, loss to follow-up, or at the end of available follow-up in our dataset (March 1, 2018). The primary statistical analysis entailed use of Cox proportional hazards models to compare the risk of dementia in people with and without liver fibrosis by calculating cause-specific hazard ratios. Proportionality of hazards was confirmed by visual inspection of survival and log-log plots. In a secondary approach, the FIB-4 score was instead treated as a linear variable to assess the association between each 1-unit increase in FIB-4 and the risk of dementia. FIB-4 was also fit as a restricted cubic spline in order to visualize the relationship with incident dementia. We constructed the following prespecified models. Model 1 was unadjusted. Model 2 was adjusted for age, sex, race/ethnicity, educational attainment, and socioeconomic deprivation. Model 3 was additionally adjusted for hypertension, diabetes, dyslipidemia, body mass index, metabolic syndrome, smoking status, and alcohol consumption frequency. Of note, hypertension and diabetes may be downstream sequelae of nonalcoholic fatty liver disease (a common cause of liver fibrosis) ${ }^{41,42}$ and therefore could be considered as potential mediators in the relationship between liver fibrosis and dementia; however, we included them as potential confounders to derive a conservative estimate of the independent contribution of liver fibrosis to dementia risk. 
We performed several sensitivity analyses. First, we replaced hypertension, diabetes, and dyslipidemia with mean systolic blood pressure, hemoglobin A1c, and total cholesterol, respectively. Second, we excluded all 2,652 participants with any known chronic liver condition at baseline to evaluate the association between subclinical liver fibrosis and incident dementia. Third, we restricted the study sample to the 36,835 participants who reported zero alcohol consumption to minimize the risk of confounding by alcohol use. We prespecified several tests of interaction with liver fibrosis in models for the primary outcome of all-cause dementia. First, effect modification by sex was assessed because stronger associations between chronic liver disease and cerebrovascular disease have been reported in women. ${ }^{43,44}$ Second, we evaluated for effect modification by metabolic syndrome. Third, we evaluated whether the association between liver fibrosis and dementia varies based on genetic risk for dementia conferred by apolipoprotein E4 carrier status. Effect modification was evaluated based on the Pvalue of cross-product terms on the multiplicative scale. The threshold of statistical significance was set at $\alpha=0.05$. All statistical analyses were performed using SAS Version 9.4 (Cary, NC), and data were visualized using R 4.0.5 (R Core Team, Vienna, Austria).

\section{Results}

From among 502,613 participants in the UK Biobank, we included 455,226 participants after exclusions (eFigure1 in the Supplement). Missing FIB-4 score data was the most frequent reason for exclusion; participants with and without missing FIB-4 score data appeared similar (eTable1 in the Supplement). The mean age of participants was 56.5 
medRxiv preprint doi: https://doi.org/10.1101/2022.02.09.22270729; this version posted February 10, 2022. The copyright holder for this preprint (which was not certified by peer review) is the author/funder, who has granted medRxiv a license to display the preprint in perpetuity. All rights reserved. No reuse allowed without permission.

Parikh et al. 11

(SD, 8.1) years, and 246,466 (54\%) were women. Clinically known liver conditions were uncommon, reported by 2,652 (0.6\%) participants. The median FIB-4 score was 1.24 (IQR, 0.97-1.57), falling in the indeterminate range. However, 9,895 (2.2\%; 95\% CI, 2.12.2\%) participants had a FIB-4 score consistent with liver fibrosis. Participants with liver fibrosis were older, more likely men, had a higher prevalence of hypertension and diabetes, and more often reported daily alcohol consumption (Table 1).

During a median follow-up of 9.0 (IQR, 8.3-9.7) years, 2,223 cases of incident all-cause dementia occurred. The rate of all-cause dementia per 1,000 person-years was 1.76 $(95 \% \mathrm{Cl}, 1.50-2.07)$ in participants with liver fibrosis and $0.52(95 \% \mathrm{Cl}, 0.50-0.54)$ in those without (Figure 1). In an unadjusted Cox proportional hazards model, participants with liver fibrosis had an increased risk of incident dementia as compared to participants without liver fibrosis (hazard ratio [HR], 3.45; 95\% Cl, 2.92-4.08). This association was attenuated and remained significant in adjusted models, including when adjusting for demographics, education, and shared risk factors for liver fibrosis and dementia (HR, 1.52; $95 \% \mathrm{Cl}, 1.22-1.90$ ) (Table 2). Findings were similar when modeling the FIB-4 score as a continuous variable (adjusted HR per unit, 1.29; 95\% Cl, 1.20-1.39) (Table 2), and visualization of the FIB-4 score as a restricted cubic spline corroborated this relationship (Figure 2).

Our findings were unchanged in a sensitivity analysis that adjusted for systolic blood pressure, hemoglobin A1c, and total cholesterol in place of corresponding categorical variables (Table 2). In additional sensitivity analyses, results were consistent after 
medRxiv preprint doi: https://doi.org/10.1101/2022.02.09.22270729; this version posted February 10, 2022. The copyright holder for this preprint (which was not certified by peer review) is the author/funder, who has granted medRxiv a license to display the preprint in perpetuity.

All rights reserved. No reuse allowed without permission.

Parikh et al. 12

excluding participants with any clinically known liver conditions at baseline and, separately, when restricting the study sample to participants reporting zero alcohol consumption at baseline (Table 2). In formal tests of interaction, the association between FIB-4 score, as a continuous variable, and incident dementia was not modified by sex $(P=0.90)$, metabolic syndrome $(P=0.23)$, or apolipoprotein $E 4$ carrier status $(P=0.25)$. There was also no effect modification by sex $(P=0.63)$, metabolic syndrome $(P=0.10)$, or apolipoprotein $E 4$ carrier status $(P=0.88)$ in models that categorized participants as having liver fibrosis based on FIB-4 score.

In terms of secondary outcomes, there were 836 cases of incident Alzheimer's disease and 467 cases of vascular dementia. Liver fibrosis was non-significantly associated with a higher risk of Alzheimer's disease in adjusted models when categorizing participants based on the FIB-4 score ( $\mathrm{HR}, 1.31 ; 95 \% \mathrm{CI}, 0.89-1.93)$, and significantly associated when treating the FIB-4 score as a continuous variable (HR per unit, $1.24 ; 95 \% \mathrm{Cl}$, 1.09-1.41). Liver fibrosis was significantly associated with an increased risk of vascular dementia in adjusted models both when treating the FIB-4 score as a categorical variable $(\mathrm{HR}, 1.64 ; 95 \% \mathrm{Cl}, 1.03-2.60)$ and continuous variable $(\mathrm{HR}, 1.24 ; 95 \% \mathrm{Cl}$, 1.05-1.46)

\section{Discussion}

In this analysis of adults in the UK Biobank cohort study, participants with liver fibrosis based on the FIB-4 liver fibrosis score had an increased risk of incident dementia independently of shared risk factors. This finding was robust to multiple sensitivity 
analyses, for example when excluding participants with any clinically known liver conditions or alcohol use.

Our findings provide new evidence that liver fibrosis is associated with a future risk of dementia at the population level. Prior studies of liver fibrosis and cognition have involved cross-sectional study designs or highly selected cohorts. For example, we previously found a cross-sectional association between liver fibrosis and cognitive performance in a population-based cohort of older Americans in the National Health and Nutrition Examination Survey, which lacks longitudinal dementia outcomes data. ${ }^{18}$ Other cross-sectional studies identified an association of liver fibrosis with worse cognitive performance in narrowly defined populations, such as in people with human immunodeficiency virus and hepatitis $\mathrm{C}$ virus infection or people with computed tomography evidence of hepatic steatosis. ${ }^{45-48}$ In this context, our study adds novel evidence that liver fibrosis is associated with worse future cognitive health in the population at large. Furthermore, this association was observed in a population with a mean age of 56.5 years at cohort entry, adding liver fibrosis to a growing list of midlife risk factors for dementia. ${ }^{49}$

There are several possible explanations for our findings. Hepatic encephalopathy is common in individuals with end-stage cirrhosis. ${ }^{50-52}$ Some individuals with liver fibrosis may have had subclinical cirrhosis or later progressed to develop clinically apparent cirrhosis. Thus, some cases of incident dementia may have partly reflected an underlying hepatic encephalopathy. For example, hepatic encephalopathy may have 
unmasked underlying cognitive impairment, and some participants with hepatic encephalopathy may have been misdiagnosed as having dementia. However, hepatic encephalopathy is typically a well-recognized syndrome unlikely to be classified as dementia, and our findings were unchanged when we excluded people with known liver conditions in a sensitivity analysis. Apart from hepatic encephalopathy, there are several additional mechanistic links between liver fibrosis and dementia. Liver fibrosis may promote the development and progression of vascular brain injury, as suggested in prior cross-sectional studies. ${ }^{53,54}$ We found an association between liver fibrosis and dementia after adjusting for vascular risk factors; shared vascular risk factors alone do not explain our findings. There is also growing evidence supporting the role of the liver in peripheral amyloid- $\beta$ clearance, with abnormal liver function potentially worsening cerebral amyloid- $\beta$ deposition. ${ }^{55-58}$ Lastly, the liver may be responsible for generating neuroprotective hepatokines, ${ }^{59}$ although the implications of liver fibrosis on such processes is not clear. Future studies should take advantage of emerging brain imaging and plasma-based biomarkers of brain health to evaluate the relative contributions of these processes.

The key strengths of this analysis are the large sample size, use of a validated liver fibrosis score, and follow-up of sufficient time to assess the impact of liver fibrosis in midlife on an age-related incident outcome. The findings should be interpreted considering several limitations. First, while validated, the FIB-4 liver fibrosis score is not a direct measure of liver fibrosis, and the use of a surrogate marker introduces the possibility of misclassification. Participants with mild liver fibrosis may be misclassified 
as having no fibrosis, for example. The consistency of our findings, whether categorizing participants based on FIB-4 scores or using FIB-4 score as continuous variable, partially mitigates the impact of misclassification introduced by cut-offs. Regardless, future studies should use more direct liver measures such as transient elastography or magnetic resonance elastography, although the feasibility of this is limited in cohorts of this size. Second, the UK Biobank does not include Alzheimer's disease biomarkers, and lacks liver-related data such as hepatokine levels and serum ammonia levels. Additionally, dementia diagnoses are ascertained based on a validated UK Biobank outcome algorithm, and this lacks specificity for Alzheimer's disease, vascular dementia, and other specific forms of dementia. Future studies should incorporate more neurocognitive data or adjudicated dementia outcome data to determine which dementia type is most impacted by the liver. Such efforts may also uncover mechanisms that underlie the link between liver fibrosis and dementia. Third, the UK Biobank study population is not representative of the UK population given the evidence of a healthy participant bias. ${ }^{60}$ In this analysis, the prevalence of liver fibrosis was approximately $2.2 \%$, which is consistent with but on the lower range of estimates from other population-based studies. ${ }^{61}$ For example, in our prior analysis of older Americans in a population-based cohort, approximately $5 \%$ had liver fibrosis by the same criteria employed in this analysis. ${ }^{18}$ The UK Biobank population is also not representative of other countries with different racial and ethnic compositions, healthrelated behavior patterns, and prevalent medical conditions. Therefore, our results may not be generalizable to the population at large. Future studies should answer whether 
medRxiv preprint doi: https://doi.org/10.1101/2022.02.09.22270729; this version posted February 10, 2022. The copyright holder for this preprint (which was not certified by peer review) is the author/funder, who has granted medRxiv a license to display the preprint in perpetuity. All rights reserved. No reuse allowed without permission.

Parikh et al. 16

liver fibrosis impacts brain health among more diverse populations, and among populations with a greater burden of comorbidities.

\section{Conclusion}

Liver fibrosis in midlife was associated with an increased future risk of dementia, including after accounting for shared risk factors and when excluding participants with clinically known liver conditions at baseline. Liver fibrosis may be an important determinant of long-term brain health outcomes. 


\section{Acknowledgements}

Authors' contributions: Dr. Parikh was responsible for conception and design of the work, analysis and interpretation of the data, drafting of the work, and giving final approval of the version to be published; and, he agrees to be accountable for all aspects of the work in ensuring that questions related to the accuracy or integrity of any part of the work are appropriately investigated and resolved. Ms. Zhang was responsible for analysis and interpretation of the data, revising the work critically for important intellectual contents, and providing final approval of the version to be published; and, she agrees to be accountable for all aspects of the work in ensuring that questions related to the accuracy or integrity of any part of the work are appropriately investigated and resolved. Drs. Kumar, Rosenblatt, Spincemaille, and Gupta were responsible for interpretation of the data, revising the work critically for important intellectual content, and providing final approval of the version to be published; and, they agree to be accountable for all aspects of the work in ensuring that questions related to the accuracy or integrity of any part of the work are appropriately investigated and resolved. Drs. Kamel, de Leon, Gottesman, and ladecola were responsible for design of the work, interpretation of the data, revising the work critically for important intellectual content, providing supervision, and giving final approval of the version to be published; and, they agree to be accountable for all aspects of the work in ensuring that questions related to the accuracy or integrity of any part of the work are appropriately investigated and resolved. 
Data Access, Reproducibility, and Analysis: Dr. Parikh and Ms. Zhang had full access to all the data in the study and take responsibility for the integrity of the data and the accuracy of the data analysis.

Conflicts of Interest and Financial Disclosures: Dr. Parikh has received personal compensation for medicolegal consulting on stroke and the New York State Empire Clinical Research Investigator Program, unrelated to this work. Dr. Kamel serves as a PI for the NIH-funded ARCADIA trial (NINDS U01NS095869) which receives in-kind study drug from the BMS-Pfizer Alliance for Eliquis ${ }^{\circledR}$ and ancillary study support from Roche Diagnostics, serves as Deputy Editor for JAMA Neurology, serves as a steering committee member of Medtronic's Stroke AF trial, serves on a trial executive committee for Janssen, and serves on an endpoint adjudication committee for a trial of empagliflozin for Boehringer-Ingelheim. Dr. de Leon is supported by the NIH (RF1 AG057570, R56 AG058913). Pascal Spincemaille is inventor on intellectual property owned by Cornell University and holds equity in Medimagemetric LLC, all unrelated to this work. Dr. ladecola serves on the Scientific Advisory Board of Broadview Ventures.

Funding: Dr. Parikh is supported by the NIH/NIA (K23 AG073524), the Leon Levy Neuroscience Fellowship, and the Florence Gould Endowment for Discovery in Stroke. 


\section{References}

1. Boyle PA, Wilson RS, Yu L, et al. Much of late life cognitive decline is not due to common neurodegenerative pathologies. Ann Neurol. 2013;74(3):478-489. doi:10.1002/ana.23964

2. Boyle PA, Yu L, Wilson RS, Leurgans SE, Schneider JA, Bennett DA. Personspecific contribution of neuropathologies to cognitive loss in old age. Ann Neurol. 2018;83(1):74-83. doi:10.1002/ana.25123

3. Chen TB, Yiao SY, Sun Y, et al. Comorbidity and dementia: A nationwide survey in Taiwan. PLoS One. 2017;12(4):e0175475. doi:10.1371/journal.pone.0175475

4. Bordet R, Deplanque D. Brain-liver axis: a new pathway for cognitive disorders related to hepatic fibrosis. Eur J Neurol. 2020;27(11):2111-2112.

doi:10.1111/ene.14454

5. Bassendine MF, Taylor-Robinson SD, Fertleman M, Khan M, Neely D. Is Alzheimer's Disease a Liver Disease of the Brain? Journal of Alzheimer's disease : JAD. 2020;75(1):1-14. doi:10.3233/JAD-190848

6. Hadjihambi A. Cerebrovascular alterations in NAFLD: Is it increasing our risk of Alzheimer's disease? Anal Biochem. 2021:114387. doi:10.1016/j.ab.2021.114387 7. Altamirano-Barrera A, Barranco-Fragoso B, Méndez-Sánchez N. Management strategies for liver fibrosis. Ann Hepatol. 2017;16(1):48-56.

doi:10.5604/16652681.1226814

8. Caballería L, Pera G, Arteaga I, et al. High Prevalence of Liver Fibrosis Among European Adults With Unknown Liver Disease: A Population-Based Study. Clin Gastroenterol Hepatol. 2018;16(7):1138-1145.e1135. doi:10.1016/j.cgh.2017.12.048 
medRxiv preprint doi: https://doi.org/10.1101/2022.02.09.22270729; this version posted February 10, 2022. The copyright holder for this preprint (which was not certified by peer review) is the author/funder, who has granted medRxiv a license to display the preprint in perpetuity. All rights reserved. No reuse allowed without permission.

Parikh et al. 20

9. Watt GP, Lee M, Pan JJ, et al. High Prevalence of Hepatic Fibrosis, Measured by Elastography, in a Population-Based Study of Mexican Americans. Clin Gastroenterol Hepatol. 2019;17(5):968-975.e965. doi:10.1016/j.cgh.2018.05.046

10. Roulot D, Costes JL, Buyck JF, et al. Transient elastography as a screening tool for liver fibrosis and cirrhosis in a community-based population aged over 45 years. Gut. 2011;60(7):977-984. doi:10.1136/gut.2010.221382

11. Koehler EM, Plompen EP, Schouten JN, et al. Presence of diabetes mellitus and steatosis is associated with liver stiffness in a general population: The Rotterdam study. Hepatology. 2016;63(1):138-147. doi:10.1002/hep.27981

12. Calvaruso V, Craxì A. Implication of normal liver enzymes in liver disease. J Viral Hepat. 2009;16(8):529-536. doi:10.1111/j.1365-2893.2009.01150.x

13. Ostovaneh MR, Ambale-Venkatesh B, Fuji T, et al. Association of Liver Fibrosis With Cardiovascular Diseases in the General Population: The Multi-Ethnic Study of Atherosclerosis (MESA). Circ Cardiovasc Imaging. 2018;11(3):e007241. doi:10.1161/CIRCIMAGING.117.007241

14. Long MT, Zhang X, Xu H, et al. Hepatic Fibrosis Associates With Multiple Cardiometabolic Disease Risk Factors: The Framingham Heart Study. Hepatology. 2021;73(2):548-559. doi:10.1002/hep.31608

15. Parikh NS, VanWagner LB, Elkind MSV, Gutierrez J. Association between nonalcoholic fatty liver disease with advanced fibrosis and stroke. Journal of the neurological sciences. 2019;407:116524. doi:10.1016/j.jns.2019.116524 
16. Parikh NS, Kamel H, Navi BB, et al. Liver Fibrosis Indices and Outcomes After Primary Intracerebral Hemorrhage. Stroke. 2020;51(3):830-837.

doi:10.1161/STROKEAHA.119.028161

17. Park JG, Jung J, Verma KK, et al. Liver stiffness by magnetic resonance elastography is associated with increased risk of cardiovascular disease in patients with non-alcoholic fatty liver disease. Aliment Pharmacol Ther. 2021;53(9):1030-1037. doi:10.1111/apt.16324

18. Parikh NS, Kumar S, Rosenblatt R, et al. Association between liver fibrosis and cognition in a nationally representative sample of older adults. Eur $\mathrm{J}$ Neurol. 2020;27(10):1895-1903. doi:10.1111/ene.14384

19. Manolio TA, Weis BK, Cowie CC, et al. New models for large prospective studies: is there a better way? Am J Epidemiol. 2012;175(9):859-866. doi:10.1093/aje/kwr453

20. UK Biobank. Validation and cleaning of externally collected data. Accessed October 1, 2021, https://biobank.ndph.ox.ac.uk/ bbdatan/Data_cleaning_overall_doc_showcase_v1.pdf 21. Kwo PY, Cohen SM, Lim JK. ACG Clinical Guideline: Evaluation of Abnormal Liver Chemistries. Am J Gastroenterol. 2017;112(1):18-35. doi:10.1038/ajg.2016.517 22. Williamson DR, Albert M, Heels-Ansdell D, et al. Thrombocytopenia in critically ill patients receiving thromboprophylaxis: frequency, risk factors, and outcomes. Chest. 2013;144(4):1207-1215. doi:10.1378/chest.13-0121 
medRxiv preprint doi: https://doi.org/10.1101/2022.02.09.22270729; this version posted February 10, 2022. The copyright holder for this preprint (which was not certified by peer review) is the author/funder, who has granted medRxiv a license to display the preprint in perpetuity.

All rights reserved. No reuse allowed without permission.

Parikh et al. 22

23. McPherson S, Stewart SF, Henderson E, Burt AD, Day CP. Simple non-invasive fibrosis scoring systems can reliably exclude advanced fibrosis in patients with nonalcoholic fatty liver disease. Gut. 2010;59(9):1265-1269. doi:10.1136/gut.2010.216077 24. McPherson S, Hardy T, Dufour JF, et al. Age as a Confounding Factor for the Accurate Non-Invasive Diagnosis of Advanced NAFLD Fibrosis. Am J Gastroenterol. 2017;112(5):740-751. doi:10.1038/ajg.2016.453

25. Vallet-Pichard A, Mallet V, Nalpas B, et al. FIB-4: an inexpensive and accurate marker of fibrosis in HCV infection. comparison with liver biopsy and fibrotest.

Hepatology. 2007;46(1):32-36. doi:10.1002/hep.21669

26. Kim BK, Kim DY, Park JY, et al. Validation of FIB-4 and comparison with other simple noninvasive indices for predicting liver fibrosis and cirrhosis in hepatitis B virusinfected patients. Liver Int. 2010;30(4):546-553. doi:10.1111/j.1478-3231.2009.02192.x 27. Naveau S, Gaudé G, Asnacios A, et al. Diagnostic and prognostic values of noninvasive biomarkers of fibrosis in patients with alcoholic liver disease. Hepatology. 2009;49(1):97-105. doi:10.1002/hep.22576

28. Xiao G, Zhu S, Xiao X, Yan L, Yang J, Wu G. Comparison of laboratory tests, ultrasound, or magnetic resonance elastography to detect fibrosis in patients with nonalcoholic fatty liver disease: A meta-analysis. Hepatology.

2017;doi:10.1002/hep.29302

29. Shah AG, Lydecker A, Murray K, et al. Comparison of noninvasive markers of fibrosis in patients with nonalcoholic fatty liver disease. Clin Gastroenterol Hepatol. 2009;7(10):1104-1112. doi:10.1016/j.cgh.2009.05.033 
30. Sterling RK, Lissen E, Clumeck N, et al. Development of a simple noninvasive index to predict significant fibrosis in patients with HIV/HCV coinfection. Hepatology. 2006;43(6):1317-1325. doi:10.1002/hep.21178

31. Hagström H, Talbäck M, Andreasson A, Walldius G, Hammar N. Ability of Noninvasive Scoring Systems to Identify Individuals in the Population at Risk for Severe Liver Disease. Gastroenterology. 2020;158(1):200-214.

doi:10.1053/j.gastro.2019.09.008

32. Yoshihisa A, Sato Y, Yokokawa T, et al. Liver fibrosis score predicts mortality in heart failure patients with preserved ejection fraction. ESC Heart Fail. 2018;5(2):262270. doi:10.1002/ehf2.12222

33. Käräjämäki AJ, Kettunen $\mathrm{O}$, Lepojärvi $S$, et al. Presence of atrial fibrillation is associated with liver stiffness in an elderly Finnish population. PLoS One. 2017;12(3):e0173855. doi:10.1371/journal.pone.0173855

34. Ginès $P$, Castera $L$, Lammert $F$, et al. Population screening for liver fibrosis: towards early diagnosis and intervention for chronic liver diseases. Hepatology. 2021;71(1):219-228. doi:10.1002/hep.32163

35. Long MT, Massaro JM, Hoffmann U, Benjamin EJ, Naimi TS. Alcohol Use is Associated with Hepatic Steatosis Among Persons with Presumed Non-alcoholic Fatty Liver Disease. Clin Gastroenterol Hepatol. 2019;18(8):1831-1841. doi:10.1016/j.cgh.2019.11.022

36. Bush K, Wilkinson T, Schnier C, Nola J, Sudlow C. Definitions of Dementia and the Major Diagnostic Pathologies, UK Biobank Phase 1 Outcomes Adjudication. 
Accessed June 1, 2021.

https://biobank.ndph.ox.ac.uk/showcase/showcase/docs/alg_outcome_dementia.pdf

37. Wilkinson T, Schnier C, Bush K, et al. Identifying dementia outcomes in UK

Biobank: a validation study of primary care, hospital admissions and mortality data. Eur

J Epidemiol. 2019;34(6):557-565. doi:10.1007/s10654-019-00499-1

38. Mackenbach, J. P., 1988. "Health and deprivation. Inequality and the North : by

P. Townsend, P. Phillimore and A. Beattie (eds.) Croom Helm Ltd, London, 1987.

39. Lumsden AL, Mulugeta A, Zhou A, Hyppönen E. Apolipoprotein E (APOE) genotype-associated disease risks: a phenome-wide, registry-based, case-control study utilising the UK Biobank. EBioMedicine. 2020;59:102954.

doi:10.1016/j.ebiom.2020.102954

40. Bycroft C, Freeman C, Petkova D, et al. The UK Biobank resource with deep phenotyping and genomic data. Nature. 2018;562(7726):203-209. doi:10.1038/s41586018-0579-z

41. Mantovani A, Petracca G, Beatrice G, Tilg H, Byrne CD, Targher G. Nonalcoholic fatty liver disease and risk of incident diabetes mellitus: an updated metaanalysis of 501022 adult individuals. Gut. 2021;70(5):962-969. doi:10.1136/gutjnl-2020322572

42. Zhao Y-C, Zhao G-J, Chen Z, She Z-G, Cai J, Li H. Nonalcoholic Fatty Liver Disease. An Emergent Driver of Hypertension. Hypertension. 2020;75(2):275-284. doi:10.1161/hypertensionaha.119.13419 
medRxiv preprint doi: https://doi.org/10.1101/2022.02.09.22270729; this version posted February 10, 2022. The copyright holder for this preprint (which was not certified by peer review) is the author/funder, who has granted medRxiv a license to display the preprint in perpetuity. All rights reserved. No reuse allowed without permission.

Parikh et al. 25

43. Alexander KS, Zakai NA, Lidofsky SD, et al. Non-alcoholic fatty liver disease, liver biomarkers and stroke risk: The Reasons for Geographic and Racial Differences in Stroke cohort. PLoS One. 2018;13(3):e0194153. doi:10.1371/journal.pone.0194153 44. Parikh NS, Koh I, Vanwagner LB, Elkind MSV, Zakai NA, Cushman M. Liver Fibrosis is Associated with Ischemic Stroke Risk in Women but not Men: The REGARDS Study. Journal of Stroke and Cerebrovascular Diseases. 2021;30(7):105788. doi:10.1016/j.jstrokecerebrovasdis.2021.105788

45. Weinstein G, Davis-Plourde K, Himali JJ, Zelber-Sagi S, Beiser AS, Seshadri S. Non-alcoholic fatty liver disease, liver fibrosis score and cognitive function in middleaged adults: The Framingham Study. Liver Int. 2019;39(9):1713-1721.

doi:10.1111/liv.14161

46. Valcour VG, Rubin LH, Obasi MU, et al. Liver Fibrosis Linked to Cognitive Performance in HIV and Hepatitis C. J Acquir Immune Defic Syndr. 2016;72(3):266-273. doi:10.1097/QAI.0000000000000957

47. Ciccarelli N, Fabbiani M, Grima P, et al. Liver fibrosis is associated with cognitive impairment in HIV-positive patients. J Int Aids Soc. 2014;17:144-145.

doi:10.7448/las.17.4.19722

48. Fabbiani M, Ciccarelli N, Castelli V, et al. Hepatitis C virus-related factors associated WITH cognitive performance in HIV-HCV-coinfected patients. J Neurovirol. 2019;25(6):866-873. doi:10.1007/s13365-019-00780-9

49. Li XY, Zhang M, Xu W, et al. Midlife Modifiable Risk Factors for Dementia: A Systematic Review and Meta-analysis of 34 Prospective Cohort Studies. Curr Alzheimer Res. 2019;16(14):1254-1268. doi:10.2174/1567205017666200103111253 
medRxiv preprint doi: https://doi.org/10.1101/2022.02.09.22270729; this version posted February 10, 2022. The copyright holder for this preprint (which was not certified by peer review) is the author/funder, who has granted medRxiv a license to display the preprint in perpetuity.

50. Ridola L, Cardinale V, Riggio O. The burden of minimal hepatic encephalopathy: from diagnosis to therapeutic strategies. Ann Gastroenterol. 2018;31(2):151-164. doi:10.20524/aog.2018.0232

51. Patidar KR, Bajaj JS. Covert and Overt Hepatic Encephalopathy: Diagnosis and Management. Clin Gastroenterol Hepatol. 2015;13(12):2048-2061.

doi:10.1016/j.cgh.2015.06.039

52. Wijdicks EF. Hepatic Encephalopathy. The New England journal of medicine. 2016;375(17):1660-1670. doi:10.1056/NEJMra1600561

53. Petta S, Tuttolomondo A, Gagliardo C, et al. The Presence of White Matter Lesions Is Associated With the Fibrosis Severity of Nonalcoholic Fatty Liver Disease. Medicine (Baltimore). 2016;95(16):e3446. doi:10.1097/MD.0000000000003446

54. Kim YD, Song D, Heo JH, et al. Relationship between Cerebral Microbleeds and Liver Stiffness Determined by Transient Elastography. PLoS One.

2015;10(9):e0139227. doi:10.1371/journal.pone.0139227

55. Nho K, Kueider-Paisley A, Ahmad S, et al. Association of Altered Liver Enzymes With Alzheimer Disease Diagnosis, Cognition, Neuroimaging Measures, and Cerebrospinal Fluid Biomarkers. JAMA Netw Open. 2019;2(7):e197978. doi:10.1001/jamanetworkopen.2019.7978

56. Xiang Y, Bu XL, Liu YH, et al. Physiological amyloid-beta clearance in the periphery and its therapeutic potential for Alzheimer's disease. Acta Neuropathol. 2015;130(4):487-499. doi:10.1007/s00401-015-1477-1

57. Wang YR, Wang QH, Zhang T, et al. Associations Between Hepatic Functions and Plasma Amyloid-Beta Levels-Implications for the Capacity of Liver in Peripheral 
Amyloid-Beta Clearance. Mol Neurobiol. 2017;54(3):2338-2344. doi:10.1007/s12035016-9826-1

58. Maarouf CL, Walker JE, Sue LI, Dugger BN, Beach TG, Serrano GE. Impaired hepatic amyloid-beta degradation in Alzheimer's disease. PLOS ONE.

2018;13(9):e0203659. doi:10.1371/journal.pone.0203659

59. Horowitz AM, Fan X, Bieri G, et al. Blood factors transfer beneficial effects of exercise on neurogenesis and cognition to the aged brain. Science.

2020;369(6500):167-173. doi:10.1126/science.aaw2622

60. Fry A, Littlejohns TJ, Sudlow C, et al. Comparison of Sociodemographic and Health-Related Characteristics of UK Biobank Participants With Those of the General Population. Am J Epidemiol. 2017;186(9):1026-1034. doi:10.1093/aje/kwx246

61. Harris R, Harman DJ, Card TR, Aithal GP, Guha IN. Prevalence of clinically significant liver disease within the general population, as defined by non-invasive markers of liver fibrosis: a systematic review. Lancet Gastroenterol Hepatol. 2017;2(4):288-297. doi:10.1016/S2468-1253(16)30205-9 
medRxiv preprint doi: https://doi.org/10.1101/2022.02.09.22270729; this version posted February 10, 2022. The copyright holder for this preprint (which was not certified by peer review) is the author/funder, who has granted medRxiv a license to display the preprint in perpetuity. All rights reserved. No reuse allowed without permission.

Parikh et al. 28

\section{Figure Legends}

Figure 1. Cumulative risk of incident all-cause dementia, stratified by liver fibrosis.

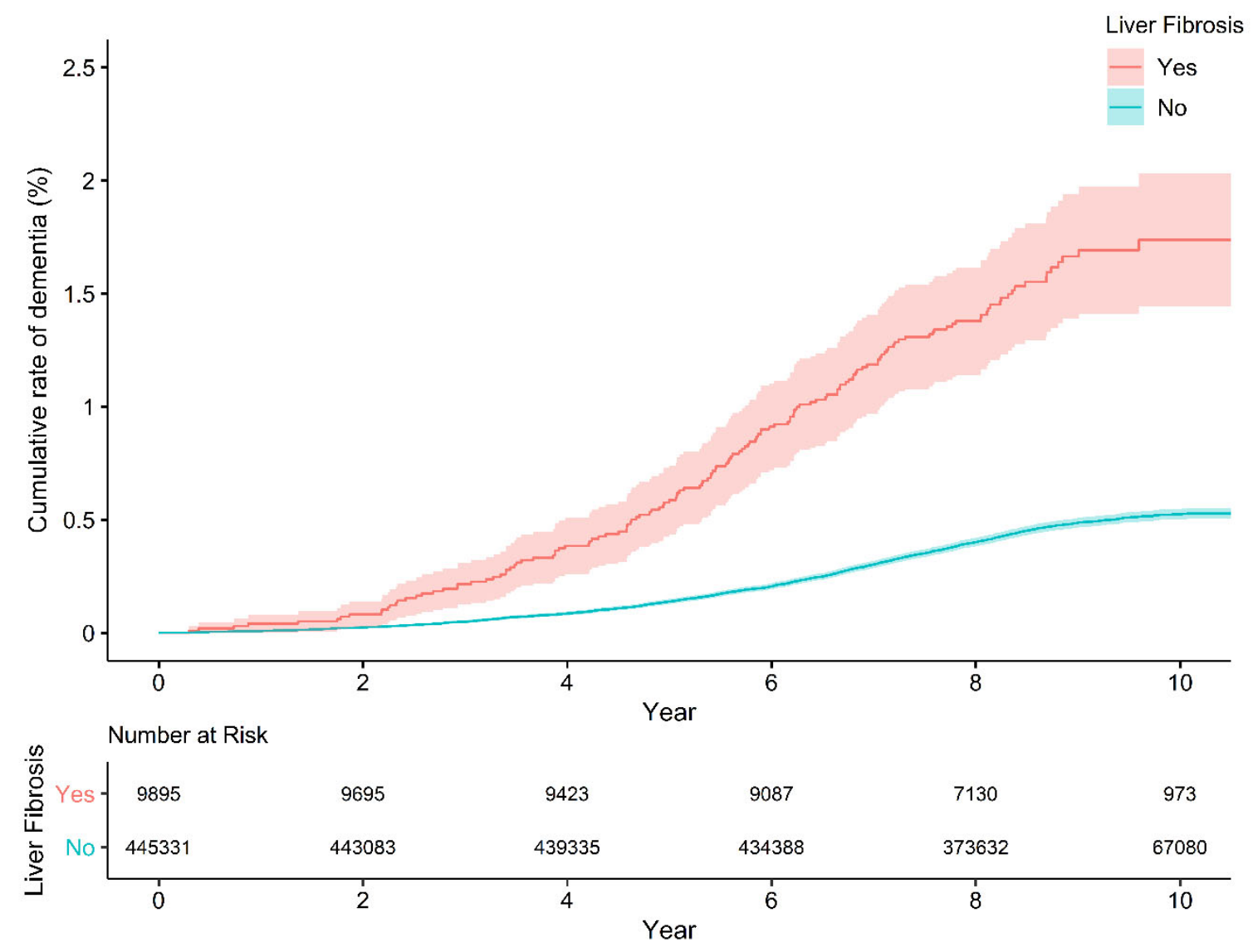

Legend: In this analysis of data from the UK Biobank prospective cohort study, participants with liver fibrosis had an increased risk of all-cause dementia. 
medRxiv preprint doi: https://doi.org/10.1101/2022.02.09.22270729; this version posted February 10, 2022. The copyright holder for this preprint (which was not certified by peer review) is the author/funder, who has granted medRxiv a license to display the preprint in perpetuity.

Parikh et al. 29

Figure 2. Relative Hazard of Incident Dementia by Fibrosis-4 Score as a Restricted Cubic Spline

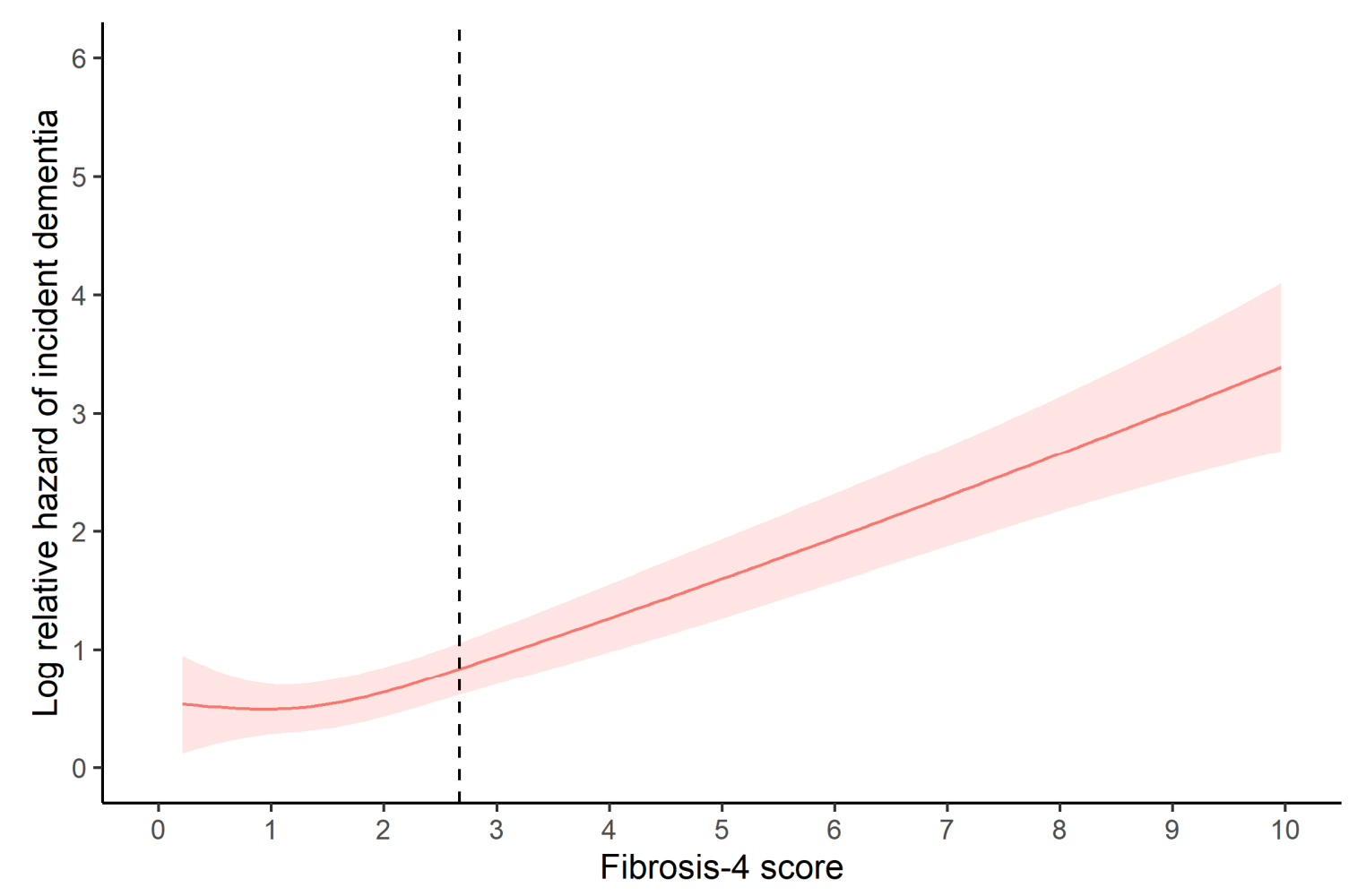

Legend: This restricted cubic spline visualization displays hazards of dementia relative to a reference Fibrosis-4 score of 2.67 , which is the cut-point used to define liver fibrosis in the primary analysis. The model was adjusted for age, sex, race/ethnicity, educational attainment, socioeconomic deprivation, hypertension, diabetes, dyslipidemia, body mass index, metabolic syndrome, smoking, and alcohol intake frequency. The shaded areas represent the $95 \%$ confidence interval band. 
Parikh et al. 30

Table 1. Baseline characteristics ${ }^{\mathrm{a}}$ of participants in the UK Biobank, stratified by liver fibrosis.

\begin{tabular}{|c|c|c|}
\hline & With Liver Fibrosis & Without Liver Fibrosis \\
\hline Participants & $\mathrm{N}=9,895$ & $\mathrm{~N}=445,331$ \\
\hline Age, years (mean, SD) & $62.5(5.9)$ & $56.4(8.1)$ \\
\hline Female & $3,334(34 \%)$ & $243,132(55 \%)$ \\
\hline \multicolumn{3}{|l|}{ Race/ethnicity ${ }^{b}$} \\
\hline Asian & $179(2 \%)$ & $9,933(2 \%)$ \\
\hline Black & $277(3 \%)$ & $6,637(2 \%)$ \\
\hline Other and multiracial & $122(1 \%)$ & $6,583(1 \%)$ \\
\hline White & $9,243(94 \%)$ & $420,130(95 \%)$ \\
\hline \multicolumn{3}{|l|}{ Education $^{c}$} \\
\hline University graduate/Professional & $3,467(47 \%)$ & $167,506(46 \%)$ \\
\hline Pre-university qualifications & $2,791(38 \%)$ & $29,119(8 \%)$ \\
\hline Vocational school completion & $788(11 \%)$ & $144,109(39 \%)$ \\
\hline Certificate of Secondary Education only & $279(4 \%)$ & $24,248(7 \%)$ \\
\hline \multicolumn{3}{|l|}{ Socioeconomic deprivation ${ }^{d}$} \\
\hline Quartile 1 (lowest deprivation) & $2,386(24 \%)$ & $112,597(25 \%)$ \\
\hline Quartile 2 & $2,369(24 \%)$ & $111,691(25 \%)$ \\
\hline Quartile 3 & $2,495(25 \%)$ & $111,255(25 \%)$ \\
\hline Quartile 4 (highest deprivation) & $2,644(27 \%)$ & $109,788(25 \%)$ \\
\hline Hypertension & $7,783(79 \%)$ & $320,159(72 \%)$ \\
\hline Systolic blood pressure, $\mathrm{mmHg}$ (mean, SD) & $142(20)$ & $138(19)$ \\
\hline Diabetes & $1,035(10 \%)$ & $25,973(6 \%)$ \\
\hline Hemoglobin A1c, \% (mean, SD) & $5.5(0.7)$ & $5.5(0.6)$ \\
\hline Dyslipidemia & $7,124(72 \%)$ & $332,933(75 \%)$ \\
\hline Total cholesterol, mg/dL (mean, SD) & $205(46)$ & $220(43)$ \\
\hline History of tobacco smoking & $6,239(63 \%)$ & $265,014(60 \%)$ \\
\hline Metabolic syndrome & $2,918(29 \%)$ & $125,639(28 \%)$ \\
\hline Body mass index, $\mathrm{kg} / \mathrm{m}^{2}$ (mean, SD) & $27.3(4.9)$ & $27.4(4.8)$ \\
\hline Known liver condition & $228(2.3 \%)$ & $2,424(0.5 \%)$ \\
\hline \multicolumn{3}{|l|}{ Alcohol consumption frequency } \\
\hline None & $969(9.8 \%)$ & $35,866(8.1 \%)$ \\
\hline Less than once weekly & $1,910(19.3 \%)$ & $100,764(22.7 \%)$ \\
\hline 1-4 times weekly & $4,241(43.0 \%)$ & $218,303(43.0 \%)$ \\
\hline Daily or almost daily & $2,755(27.9 \%)$ & $89,893(20.2 \%)$ \\
\hline Aspartate aminotransferase, IU/L (median, IQR) & $34(27-49)$ & $24(21-29)$ \\
\hline Alanine aminotransferase, IU/L (median, IQR) & $22(15-34)$ & $20(15-27)$ \\
\hline Platelet count, $10^{9}$ cells/liter (median, IQR) & $155(127-182)$ & $250(216-288)$ \\
\hline Albumin, g/dl (median, IQR) & $4.5(4.3-4.7)$ & $4.5(4.4-4.7)$ \\
\hline \multicolumn{3}{|c|}{$\begin{array}{l}\text { Abbreviations: SD, standard deviation; mmHg, millimeters mercury; } \mathrm{mg} / \mathrm{dL} \text {, milligrams per deciliter; } \mathrm{kg} / \mathrm{m}^{2} \text {, } \\
\text { kilograms per meter-squared; IU/L, international units per liter; IQR, interquartile range; g/dl, grams per deciliter. } \\
\text { aData are presented as percentage }(95 \% \text { confidence interval of percentage) unless otherwise specified. } \\
\text { Percentages for any given characteristic may not sum to } 100 \% \text { because of rounding. } \\
\text { b Race/ethnicity groupings based on UK Biobank population composition. } \\
\text { cEducation categorized based on UK educational system. A and O level certifications indicate higher educational } \\
\text { attainment than Certificate of Secondary Education. } \\
\text { dSocioeconomic deprivation measured using the Townsend deprivation index, reflecting employment status, } \\
\text { automobile ownership, home ownership, and household crowding; higher scores indicate worse socioeconomic } \\
\text { deprivation. }\end{array}$} \\
\hline
\end{tabular}


medRxiv preprint doi: https://doi.org/10.1101/2022.02.09.22270729; this version posted February 10, 2022. The copyright holder for this preprint (which was not certified by peer review) is the author/funder, who has granted medRxiv a license to display the preprint in perpetuity.

All rights reserved. No reuse allowed without permission.

Parikh et al. 31

Table 2. Association ${ }^{\mathrm{a}}$ of Liver Fibrosis with Incident Dementia in the UK Biobank.

\begin{tabular}{|c|c|c|}
\hline Model & $\begin{array}{c}\text { Liver Fibrosis versus } \\
\text { no Liver Fibrosis }\end{array}$ & $\begin{array}{l}\text { For each } 1.0 \text { unit } \\
\text { increase in FIB-4 }\end{array}$ \\
\hline Model 1: Unadjusted & $3.45(2.92-4.08)$ & $1.60(1.56-1.64)$ \\
\hline Model 2: Adjusted for sociodemographics ${ }^{b}$ & $1.60(1.29-1.99)$ & $1.32(1.23-1.42)$ \\
\hline Model 3: Adjusted for sociodemographics, comorbidities ${ }^{c}$ & $1.52(1.22-1.90)$ & $1.29(1.20-1.39)$ \\
\hline Sensitivity analysis $1^{\mathrm{d}}$ & $1.51(1.19-1.91)$ & $1.30(1.20-1.40)$ \\
\hline Sensitivity analysis $2^{e}$ & $1.45(1.16-1.83)$ & $1.26(1.17-1.36)$ \\
\hline Sensitivity analysis $3^{f}$ & $1.96(1.12-3.43)$ & $1.27(1.04-1.55)$ \\
\hline $\begin{array}{l}\text { Abbreviations: FIB-4, Fibrosis-4 score. } \\
\text { aReported as hazard ratio ( } 95 \% \text { confidence interval). } \\
\text { b Age, sex, race/ethnicity, educational attainment, and soc } \\
\text { cHypertension, diabetes, dyslipidemia, body mass index, } \\
\text { frequency. } \\
\text { d'Systolic blood pressure, hemoglobin A1c, and total chole } \\
\text { placed of hypertension, diabetes, and dyslipidemia, respe } \\
\text { eExcluded participants with any clinically known liver con } \\
\text { fExcluded participants with any non-zero alcohol consumb }\end{array}$ & $\begin{array}{l}\text { conomic deprivation. } \\
\text { tabolic syndrome, smol } \\
\text { erol were used as contir } \\
\text { vely. } \\
\text { on at baseline. } \\
\text { ons at baseline. }\end{array}$ & $\begin{array}{l}\text { and alcohol intake } \\
\text { s covariates in }\end{array}$ \\
\hline
\end{tabular}

